\title{
Changes in the Number of Preantral Follicles and Hormone Concentrations in the Bovine Fetus
}

\author{
Yuki MURANISHI ${ }^{1)}$, Tomas J. ACOSTA ${ }^{1)}$, Akio MIYAMOTO ${ }^{1)}$ and \\ Yutaka FUKUI ${ }^{1)}$
}

1) Laboratory of Animal Genetics and Reproduction, Obihiro University of Agriculture and Veterinary Medicine, Obihiro 080-8555, Japan

\begin{abstract}
The present study aimed to determine the relationship among changes in the number of primordial and primary follicles, ovarian weight and concentrations of androstenedione (A), estradiol-17 $\beta\left(\mathrm{E}_{2}\right)$, progesterone $\left(\mathrm{P}_{4}\right)$, follicle-stimulating hormone $(\mathrm{FSH})$ and luteinizing hormone $(\mathrm{LH})$ in the bovine fetus between day- 90 and -150 of gestation. Fetal ovaries were obtained from 25 pregnant cows. Histological sections of the ovaries were examined to determine the number of preantral follicles. The hormone concentrations were determined by enzyme immunoassay. Ovarian weight increased in parallel with fetal age. No clear changes in the number of primordial follicles were observed in this period. Primary follicles were observed in ovarian sections at day-100 and the number of primary follicles increased in parallel with fetal age between day-90 and -120 , and afterwards it significantly increased $(p<0.05)$ at day-130. Around day-120, the number of primary follicles increased with the serum concentrations of $\mathrm{A}$ and $\mathrm{E}_{2}$. However, no relationships among number of primary follicles and concentrations of FSH and LH were observed in this period. These results indicate that the number of primary follicles markedly increases around day-130 of gestation, the increase in the number of primary follicles is associated with an increase in the concentrations of $\mathrm{A}$ and $E_{2}$ in the fetal serum, and the growth and differentiation of primordial and primary follicles are independent of FSH and LH.

Key words: Primordial follicle, Primary follicle, Steroid hormone (A, $\mathrm{E}_{2}$ and $\mathrm{P}_{4}$ ), Gonadotropin (FSH and LH), Bovine fetal
\end{abstract}

(J. Reprod. Dev. 48: 553-560, 2002)

T he mammalian ovary contains a large number of preantral follicles. About 2 million germ cells were found in the bovine fetal ovaries at day90 of gestation [1,2]. A drastic change in the number of preantral follicles as well as in the ovarian weight has been observed in the bovine fetus between day-90 and -150 of gestation $[1,3]$. The number of follicles rapidly decreases after this period, but about 20 thousand preantral follicles were still found at birth in the calf [1]. From these follicles, only a few follicles grow and reach a final

Accepted for publication: June 5, 2002

Correspondence: Y. Fukui ovulatory size throughout the reproductive life of the adult female. More than $99.9 \%$ of preantral and antral follicles undergo degenerative changes during growth and the maturation process [4]. This represents a tremendous loss of valuable genetic resources.

Follicle-stimulating hormone (FSH) induces follicular development in the ovaries of adult mammals [1]. FSH stimulates the activity of aromatase that converts androgens to estrogen in follicular cells [5]. Aromatase activity has been found in the bovine fetal ovaries at an early stage of pregnancy $[6,7]$. FSH stimulates the activity of 
aromatase and accelerates the production of estrogen. The proliferation of granulosa cells in the follicles is enhanced by an autocrine action of estrogen, which is stimulated by FSH. Estradiol production in fetal ovaries has also been shown in cattle $[8,9]$. Recently, it has been demonstrated that bovine oocytes obtained from secondary follicles can achieve complete maturation in vitro [4]. However, a culture system for bovine primordial and primary follicles is still lacking [10-13]. Therefore, the present study aimed to determine the relationships among changes in the number of primordial and primary follicles, ovarian weight and concentrations of androstenedione(A), estradiol-17 $\beta\left(\mathrm{E}_{2}\right)$, progesterone $\left(\mathrm{P}_{4}\right), \mathrm{FSH}$ and luteinizing hormone $(\mathrm{LH})$ in bovine fetuses between day-90 and -150 of gestation.

\section{Materials and Methods}

\section{Fetuses}

Fetuses were collected from 25 pregnant Holstein cows at a local slaughterhouse and transported to the laboratory. Fetal age was estimated from the crown-rump length (CRL) according to the methods described by Salisbury and Van Demark [14]. The fetal ages ranged from day- 90 to 150 of gestation and were divided into six groups (Group I: day-90 to 99, Group II: day-100 to 109, Group III: day-110 to 119, Group IV: day-120 to 129, Group V: day-130 to 139, Group VI: day-140 to 149 of gestation).

\section{Fetal serum}

Fetal blood was obtained from the heart using a 21-gauge needle connected to a plastic syringe, transferred to a 5-ml spits-tube, and centrifuged at $2,000 \times \mathrm{g}$ for $20 \mathrm{~min}$ at $4 \mathrm{C}$. The supernatant was frozen and stored at $-30 \mathrm{C}$ until use.

\section{Histology}

Both ovaries were aseptically removed from the abdominal cavity, and separated from surrounding connective tissue. The weight of each ovary was measured separately and averaged for both ovaries. Each ovary was cut around the center along the long axis, fixed in $10 \%$ formalin solution and embedded in paraffin. Serial sections $4 \mu \mathrm{m}$ in thickness were cut and mounted on gelatin-coated slides (MUTO-GRASS, Japan). The slides were stained with hematoxylin and eosin, and examined using a microscope (Nikon, Japan). Follicular stages were determined based on the follicular diameter and the morphology of the oocytes surrounding cells. The follicles were classified according to previously established methods $[1,15$, 16] as follows: 1) primordial follicles; $\leq 40 \mu \mathrm{m}$ of diameter, oocytes surrounded by germ epithelial cells (pre-granulosa cells), 2) primary follicles; 40$\leq 60 \mu \mathrm{m}$ of diameter, oocytes surrounded by one layer of cubic or columnar granulosa cells without differentiated theca cells. Because no difference in the relative number of follicles was found in the serial sections of each ovary, the number of follicles counted in the section of both ovaries (left + right) was considered as the representative number of primordial and primary follicles for each fetus.

\section{Hormone determinations}

The serum concentrations of the hormones in each fetus were determined in duplicate by doubleantibody enzyme immunoassay (EIA) using 96well ELISA plates (Corning Glass Worls, Corning, $N Y)$. Serum concentrations of steroids $\left(E_{2}, A\right.$ and $\mathrm{P}_{4}$ ) were determined after diethylether extraction. The EIA for $E_{2}$ was carried out as described previously [17]. The standard curve ranged from 2 to 2,000 pg/ml, and the ED50 of the assay was 105 $\mathrm{pg} / \mathrm{ml}$. The intra- and inter-assay CVs were 6.5 and $7.3 \%$, respectively. The EIA for A has been described previously [18]. The A standard curve ranged from 2 to $1,000 \mathrm{pg} / \mathrm{ml}$, and the $\mathrm{ED}_{50}$ of the assay was $130 \mathrm{pg} / \mathrm{ml}$. The intra- and inter-assay CVs were 6.8 and $8.1 \%$, respectively. The EIA for $\mathrm{P}_{4}$ was also performed as previously described [19]. The standard curve ranged from 20 to $20,000 \mathrm{pg} /$ $\mathrm{ml}$, and the $\mathrm{ED}_{50}$ of the assay was $850 \mathrm{pg} / \mathrm{ml}$. The intra- and inter-assay CVs were 4.8 and $6.6 \%$, respectively. The recovery rates of $\mathrm{A}_{2} \mathrm{E}_{2}$ and $\mathrm{P}_{4}$ were 81,75 and $92 \%$, respectively.

The serum levels of LH and FSH were also determined by EIA. The EIA for LH determination was based on the streptavidin-biotin technique as previously described by Mutayoba et al. [20]. The standard curve for LH ranged from 0.2 to $200 \mathrm{ng} /$ $\mathrm{ml}$ and the $\mathrm{ED}_{50}$ of the assay was $10.5 \mathrm{ng} / \mathrm{ml}$. The intra- and inter-assay CVs were 8.5 and $13.5 \%$, respectively. FSH was measured by a modification of the method previously reported by Watanabe et al. [21]. The standard curve ranged from 0.02 to 40 $\mathrm{ng} / \mathrm{ml}$ and the $\mathrm{ED}_{50}$ of the assay was $1.1 \mathrm{ng} / \mathrm{ml}$. 
The intra-and inter-assay CVs were 13.8 and $16.7 \%$, respectively.

\section{Statistical analysis}

All values are presented as the mean \pm SEM. The quantitative data obtained from EIA (A, $\mathrm{E}_{2}, \mathrm{P}_{4}, \mathrm{FSH}$ and $\mathrm{LH}$ ) were compared among the different groups using ANOVA (Excel) followed by Student's t-test. A value of $\mathrm{P}<0.05$ was considered significant.

\section{Results}

\section{Ovarian weight}

The mean weight ( \pm SEM) of the ovaries from the bovine fetuses at day-90 was $51.2 \pm 4.0 \mathrm{mg}(\mathrm{n}=4)$. This value increased significantly $\left(\mathrm{P}<0.05: \mathrm{R}^{2}=0.17\right)$ with gestational age at day-140 $(63.3 \pm 10.1 \mathrm{mg}: \mathrm{n}=$ 5) (Fig. 1).

\section{Primordial and primary follicles}

Primordial follicles were observed only in the cortex layer of the ovary (Fig. 2-A). Changes in the number of primordial follicles in fetal ovaries between day- 90 and -150 of gestation are shown in Fig. 3-A. During this period, significant changes in the number of primordial follicles were not found. Primary follicles were observed in the deep cortex layer (Fig. 2-B). The mean number of primary follicles in each ovarian section is shown in Fig. 3-B. Primary follicles were observed in ovarian sections at day-100 and the number of primary follicles increased in parallel with fetal age, and significantly increased $(\mathrm{p}<0.05)$ at day-130. No secondary follicles ( $\geq 60 \mu \mathrm{m}$ of diameter, an oocyte surrounded by one layer of cubic or columnar granulosa cells) or early antral follicles were observed in the fetal ovaries examined in this study.

\section{Serum levels of hormones}

Fig. 4 shows the change in serum levels of $A, E_{2}$, $\mathrm{P}_{4}, \mathrm{LH}$ and FSH in the fetus. The mean concentration of $\mathrm{E}_{2}$ in Group I was $4.4 \pm 1.9 \mathrm{pg} / \mathrm{ml}$. Afterwards, the $\mathrm{E}_{2}$ level gradually increased up to day-120 $(26.0 \pm 6.9 \mathrm{pg} / \mathrm{ml})$, when the number of primary follicles began to increase. The serum A concentration in the Groups III, IV, V (mean value for three groups: $274.8 \pm 23.4 \mathrm{pg} / \mathrm{ml}$ ) was significantly higher $(\mathrm{p}<0.05)$ than those of Group I $(70.2 \pm 20.6 \mathrm{pg} / \mathrm{ml})$. The serum levels of $\mathrm{A}$ and $\mathrm{E}_{2}$ increased up to day-120. The mean $\mathrm{P}_{4}$ concentration from day-90 to 99 was $39.0 \pm 14.2 \mathrm{pg} /$ $\mathrm{ml}$. The $\mathrm{P}_{4}$ concentration gradually increased up to day-120 $(101.5 \pm 25.0 \mathrm{pg} / \mathrm{ml})$, but afterwards the $\mathrm{P}_{4}$ values decreased to the same levels observed at day-90 to 99 . The mean $\mathrm{LH}$ concentration from

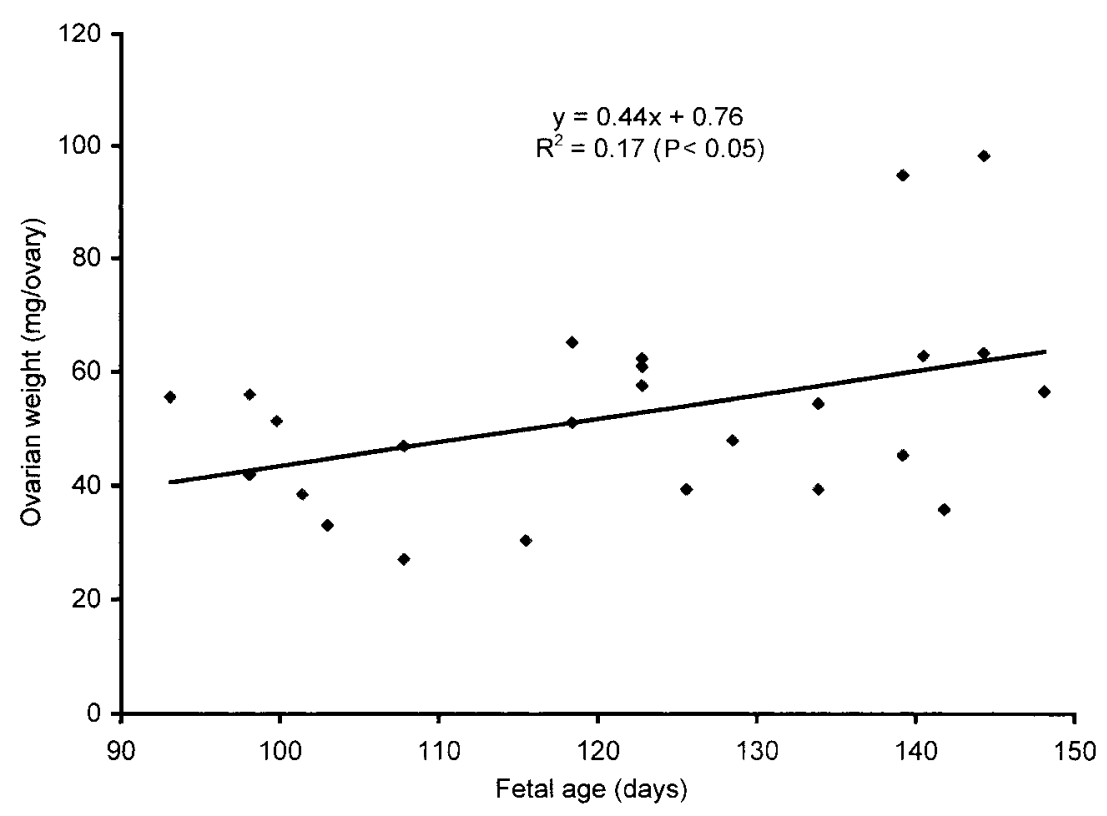

Fig. 1. Changes in ovarian weight with fetal age in the bovine fetus $(n=25)$. 

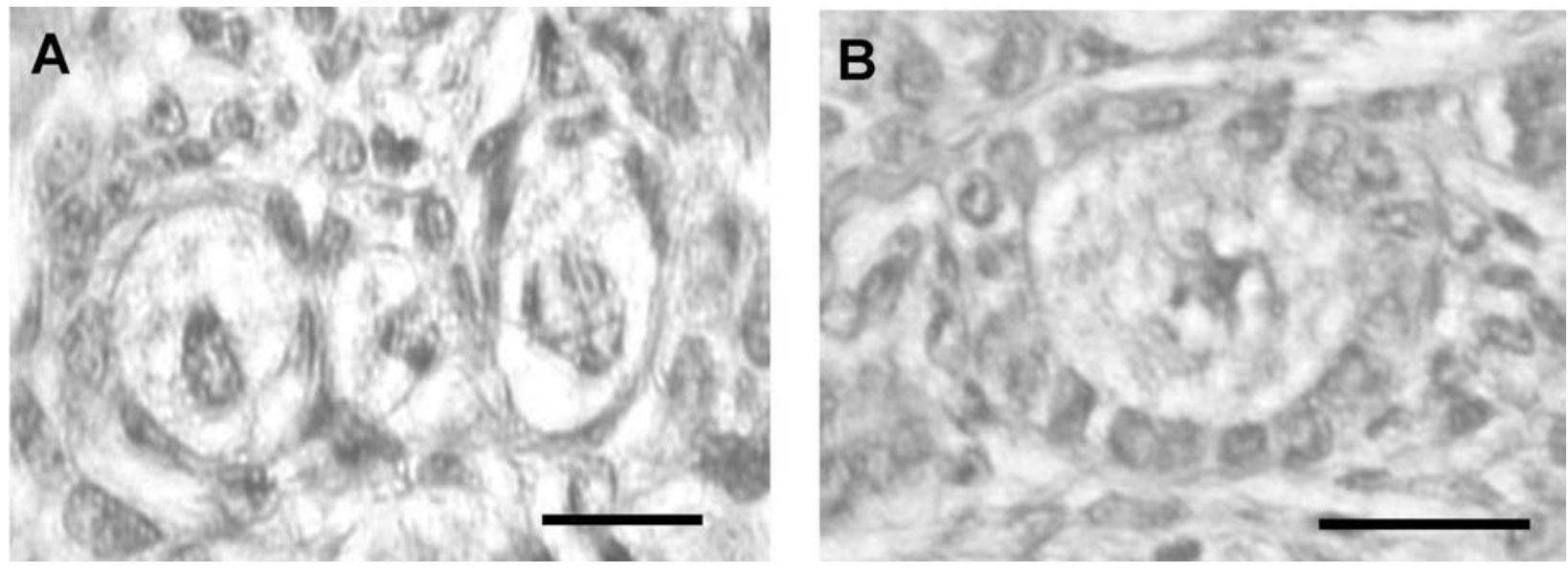

Fig. 2. Representative primordial (A) and primary (B) follicles in bovine fetal ovaries. Scale bars: $20 \mu \mathrm{m}$.

day-90 to 99 was $3.4 \pm 0.9 \mathrm{ng} / \mathrm{ml}$, and did not change during the observation period. The mean FSH concentration from day-90 to 99 was $1.0 \pm 0.5$ $\mathrm{ng} / \mathrm{ml}$. At day-110, the FSH concentration tended to be higher than the values of earlier periods, but decreased at around day-120 of gestation.

\section{Discussion}

In the present study, bovine fetal ovarian weight increased with gestational age from day-90 to 150 of gestation. Other studies [1,3] have reported that fetal ovarian weight remains relatively constant between day-120 and -177, but markedly increases after day-180 of gestation. The period between day- 90 and -150 of gestation is a time of drastic increase in the number of germ cells and preantral follicular development in the fetal ovary $[1,2]$. The growth of the follicles including the increase in the diameter of the oocyte, proliferation of the granulosa cells and differentiation of the surrounding stromal cells into theca cells are followed by the formation of new blood vessels in the adjacent interstitial tissue. These changes in the follicular structure may result in an increase in the ovarian weight and mass during this period.

The results of the present study are consistent with those of Rüsse [2], who reported that the number of primordial follicles did not change between day-90 and -150 of gestation. However, in the study of Rüsse [2], primary follicles were first observed in fetal ovaries at day-140 of gestation. On the other hand, Tanaka et al. [1] reported that the primary follicles appeared at day-100, as was also observed in the present study. The mechanism leading to spontaneous growth, development, and differentiation of some resting primordial follicles to primary follicles remains unknown at present. The first sign that primordial follicles and their corresponding oocytes have entered into the growth phase is the morphological change of the surrounding granulosa cells. The granulosa cells proliferate and change from flattened-shape in primordial follicles to cuboidal-shape cells in primary follicles. Following the growth process, follicles increase in size through a series of mitotic divisions of the granulosa cells [4], and unilaminar primary follicles are converted into multilaminar secondary follicles. In the present study, the secondary follicle was not observed up to day- 150 of pregnancy.

In the present study, primary follicles were observed in ovarian sections at day-100 of gestation. The number of primary follicles increased markedly around day-130 of gestation. This increase in the number of primary follicles was associated with an increase in the concentrations of $A$ and $E_{2}$ in the fetal serum. The main route for steroid production in the bovine fetal ovary appears to be the androstenedione-estroneestradiol pathway [7], and it was postulated that this shift in steroid biosynthetic pathways might be related to changes in cellular events from mitosis to meiosis in fetal ovaries. In the present study, the serum levels of $\mathrm{A}, \mathrm{E}_{2}$ and $\mathrm{P}_{4}$ increased in parallel up to day-120. The concentration of $\mathrm{P}_{4}$ after day- 120 decreased to the same levels observed between 
A

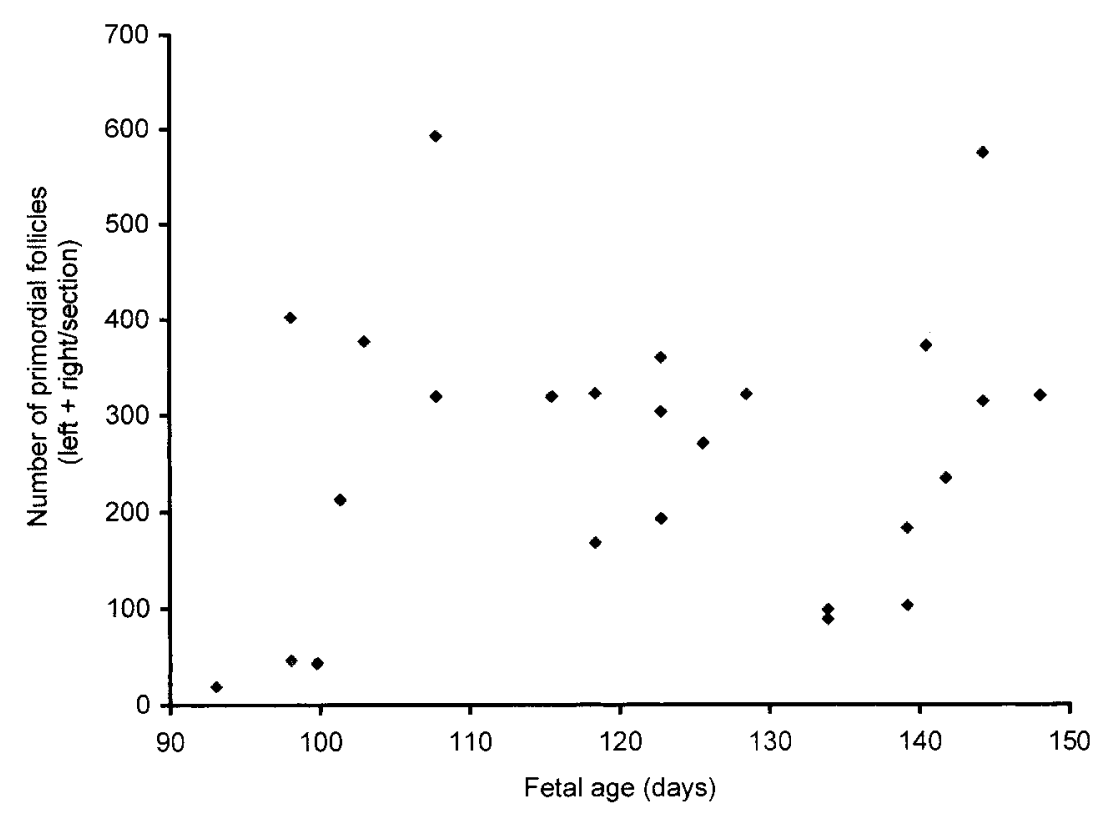

B

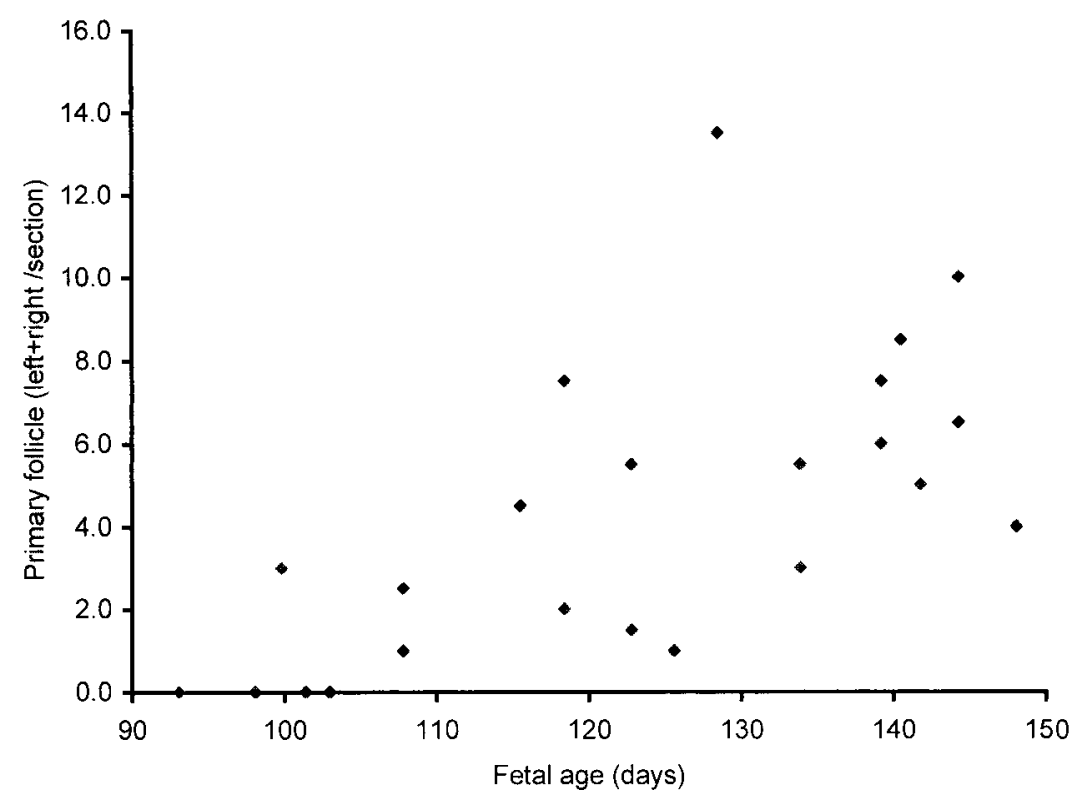

Fig. 3. Changes in the number of primordial (A) and primary (B) follicles in bovine fetal ovaries $(n=25)$.

day-90 and -99, while $A$ and $E_{2}$ concentrations remained relatively high. Androstenedione is mainly synthesized from $\mathrm{P}_{4}$ through the $\Delta 4$ pathway after LH stimulation in fetal ovaries [8]. As primordial follicles do not have differentiated theca cells, LH receptors may be absent in primordial follicles. Therefore, it seems that the changing pattern of $\mathrm{P}_{4}$ and other steroids $\left(\mathrm{A}\right.$ and $\left.\mathrm{E}_{2}\right)$ may be independent. Shemesh et al. [8] reported that $\mathrm{P}_{4}$ and $\mathrm{E}_{2}$ concentrations started to increase in the fetal ovary on day- 30 and -42 , respectively. In other studies $[8,9], E_{2}$ was undetectable in fetal ovaries at day-70 and -105 of pregnancy. Acosta et al. [18] showed that $\mathrm{P}_{4}$ concentrations in the fetal 

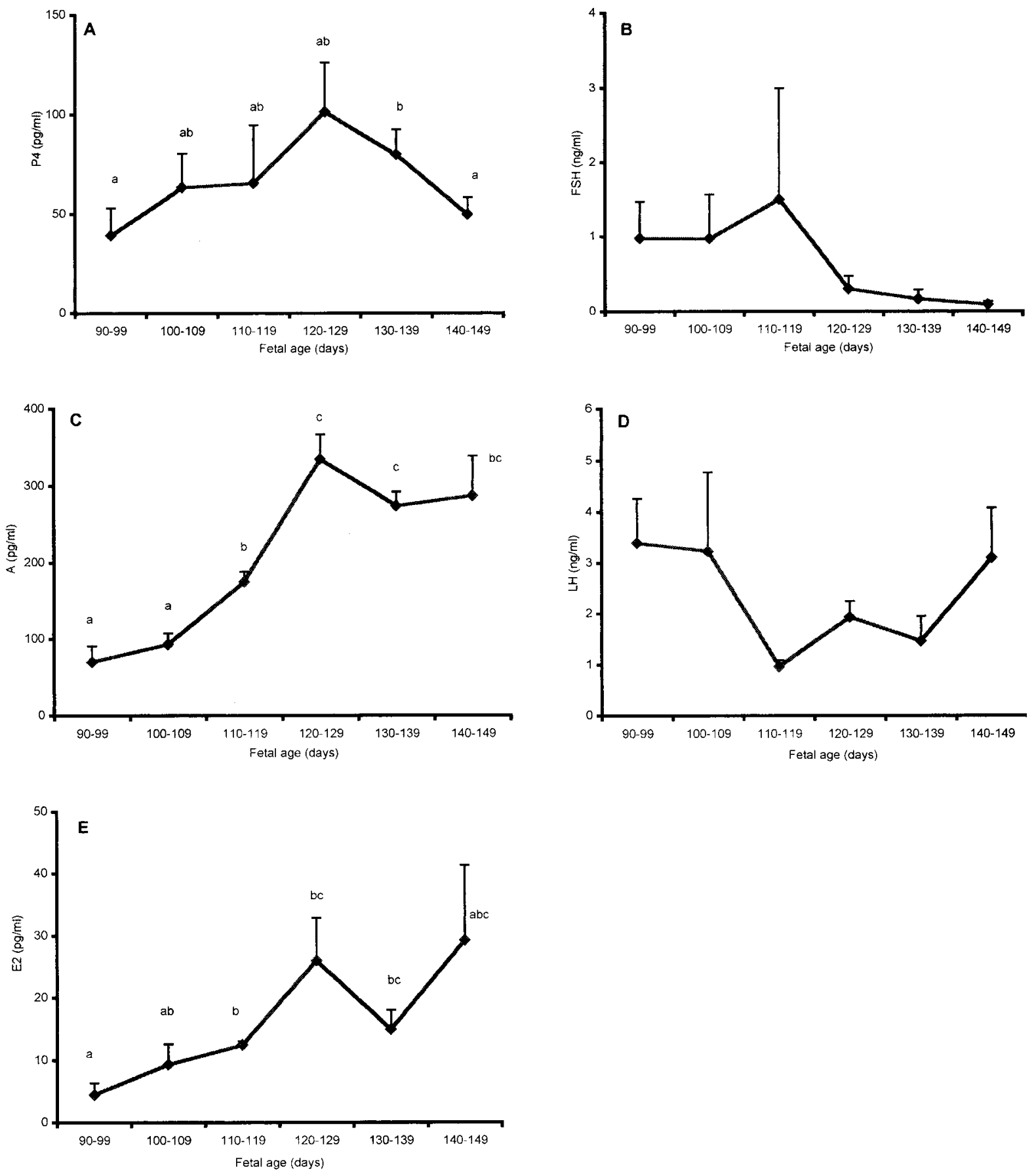

Fig. 4. Changes in serum concentrations of steroid hormones $\left(\mathrm{A}, \mathrm{E}_{2}, \mathrm{P}_{4}\right)$ and gonadotoropins (FSH, LH) in the bovine fetus. $a, b$, c: Values with different superscripts are significantly different $(\mathrm{P}<0.05)$.

sera were lower than that in the maternal sera, but the fact that the concentrations of $\mathrm{A}$ and $\mathrm{E}_{2}$ in fetal sera were higher than those in maternal sera suggests that these two steroids ( $\mathrm{A}$ and $\mathrm{E}_{2}$ ) are of fetal origin. From the above result, since the increase in two steroids ( $\mathrm{A}$ and $\mathrm{E}_{2}$ ) was coincident with the appearance of primary follicles, we consider that fetal originated steroid hormones may support the growth of primordial follicles into primary follicles. 
The concentrations of gonadotropins (FSH and LH) showed a large variation and did not show clear changes during the observation period. It was reported that LH was not able to cross the placental barrier in the sheep [22]. Therefore, it is likely that the LH detected in the present study was of fetal origin. Secondary follicles may develop LH receptors in their differentiated theca cells. As theca cells were not observed in primordial and primary follicles, it appears that LH may not affect follicular growth during the observation period of the present study. FSH has been reported to promote follicular development in cultured bovine preantral follicles [1], and FSH may play a role in the early follicular development that occurs in the bovine fetal ovary [23]. Bao et al. [5] reported that FSH receptors are present in the granulosa cells of bovine primary follicles which may respond to a low concentration of FSH. However, our results and those of a previous study [24] suggest that the development of primordial and primary follicles is not associated with either gonadotropin.

In conclusion, the number of primary follicles markedly increased around day-130 of gestation in the bovine fetal ovary, the increase in the number of primary follicles was associated with increases in the concentrations of $A$ and $E_{2}$ in the fetal serum, and the growth and differentiation of primordial and primary follicles appeared to be independent of FSH and LH.

\section{Acknowledgments}

The authors thank Dr. K. Okuda, Okayama University, Japan, for providing progesterone antiserum and to Obihiro Livestock Corporation for providing bovine fetuses.

\section{References}

1. Tanaka Y, Nakada K, Moriyoshi M, Sawamukai Y. Appearance and number of follicles and change in the concentration of serum FSH in female bovine fetuses. Reproduction 2001; 121: 777-782.

2. Rüsse I. Oogenesis in cattle and sheep. Biblthca Anat 1983; 24: 77-92

3. Ericson BH. Development and senescence of the postnatal bovine ovary. J Anim Sci 1966; 25: 800-805.

4. Yamamoto K, Otoi T, Koyama N, Horikita N, Tachikawa S, Miyano T. Development to live young from bovine small oocytes after growth, maturation and fertilization in vitro. Theriogenology 1999; 52: 81-89.

5. Bao B, Garverick HA, Smith GW, Smith MF, Salfen BE, Youngquist RS. Changes in mRNA encoding LH receptor, cytochrome P450 side chain cleavage and aromatase are associated with recruitment and selection of bovine ovarian follicles. Biol Reprod 1997; 56: 1158-1168.

6. Juarez-Oropeza MA, Alvarez-Fernandez G, Lopez V, Kawa S, Pedernera E. Steroid metabolism in the cortex and the medulla of the early fetal bovine ovary. J Exp Zool 1993; 266: 102-107.

7. Dominguez MM, Liptrap RM, Basrur PK. Steroidogenesis in fetal bovine gonads. Can J Vet Res 1988; 52: 401-406.

8. Shemesh M, Ailenberg M, Ayalon N, Hansel W. Hormone secretion by cultured bovine pre- and postimplantation gonads. Biol Reprod 1978; 19: 761767.

9. Shemesh M. Estradiol-17 $\beta$ biosynthesis by the early bovine fetal ovary during the active and refractory phases. Biol Reprod 1980; 23: 577-582.

10. Amorim C, Lucci C, Rodrigues A, Carvalho F, Figueiredo J, Rondina D, Cecchi R, Giorgetti A, Martini A, Goncalvis P. Quantitative and qualitative analysis of the effectiveness of a mechanical method for the isolation of preantral follicles from ovine ovaries. Theriogenology 2000; 53: 1251-1262.

11. Saha S, Shimizu M, Geshi $\mathbf{M}$, Izaike $\mathbf{Y}$. In vitro culture of bovine preantral follicles. Anim Reprod Sci 2000; 63: 27-39.

12. Fortune JE, Kito S, Wandji SA, Srsen V. Activation of bovine and baboon primordial follicles in vitro. Theriogenology 1998; 49: 441-449.

13. Van den Hurk R, Bevers MM, Beckers JF. In vivo and in vitro development of preantral follicles. Theriogenology 1997; 47: 73-82.

14. Salisbury GW, VanDemark NL. Gestation. In: Salisbury GW, VanDemark NL (eds.), Physiology of Reproduction and Artificial Insemination of Cattle. San Francisco and London: W. H. Feeman \& Company, 1961; 121-125.

15. Hulsof SC, Figueiredo JR, Beckers JF, Bevers MM. Isolation and characterization of preantral follicles from foetal bovine ovaries. Vet Quart 1994; 16: 78-80.

16. Carambula SF, Goncalves PBD, Costa LFS, Figueiredo JR, Wheeler MB, Neves JP, Mondadori RG. Effect of fetal age and method of recovery on isolation of preantral follicles from bovine ovaries. Theriogenology 1999; 52: 563-571. 
17. Wijayagunawardane $\mathbf{M}$, Miyamoto A, Cerbito W, Acosta TJ, Takagi M, Sato K. Local distributions of oviductal estradiol, progesterone, prostaglandins, oxytocin and endothelin-1 in the cyclic cow. Theriogenology 1998; 49: 607-618.

18. Acosta TJ, Miyamoto A, Ozawa T, Wijayagunawardane MP, Sato K. Local release of steroid hormones, prostaglandin $\mathrm{E}_{2}$, and endothelin1 from bovine mature follicles in vitro: effects of luteinizing hormone, endothelin-1, and cytokines. Biol Reprod 1998; 59: 437-443.

19. Miyamoto A, Okuda K, Schweigert F, Schams D. Effects of basic fibroblast growth factor, transforming growth factor on the secretory function of the bovine corpus luteum in vitro. J Endocrinol 1992; 135: 1032-1114.

20. Mutayoba B, Meyer H, Schams D, Schallenberger E. Development of a sensitive enzyme-immuno- assay for LH determination in bovine plasma using the streptavidin-biotin technique. Acta Endocrinol (Copenh) 1990; 122: 227-232.

21. Watanabe H, Miyamoto A, Fukui Y. A competitive enzymeimunoassay for follicle-stimulating hormone in ovine plasma using biotinstreptavidine amplification. Reprod Fertil Dev 1997; 9: 597-601.

22. Foster DL, Karsch FJ, Nalbandov AV. Regulation of luteinizing hormone (LH) in the fetal and neonatal lamb. II. Study of placental transfer of LH in the sheep. Endocrinology 1972; 90: 253-257.

23. Fortune HE, Kito S, Byrd DD. Activation of primordial follicles in vitro. J Reprod Fertil 1999; 54: 439-448.

24. Robert E, Gore-Langton RE, Armstrong DT. Follicular steroidogenesis and its control. In: Knobil E, Neill J (eds.), The Physiology of Reproduction. New York: Ravan Press. 1988; 331-385. 